Summer 2005

\title{
The Treaty Establishing a Constitution for Europe and the Democratic Legitimacy of the European Union
}

\author{
Elisabeth Zoller \\ University of Newcastle, Tyne, ezoller@indiana.edu
}

Follow this and additional works at: https://www.repository.law.indiana.edu/ijgls

Part of the Constitutional Law Commons, European Law Commons, and the International Law

\section{Commons}

\section{Recommended Citation}

Zoller, Elisabeth (2005) "The Treaty Establishing a Constitution for Europe and the Democratic Legitimacy of the European Union," Indiana Journal of Global Legal Studies: Vol. 12 : Iss. 2 , Article 2.

Available at: https://www.repository.law.indiana.edu/ijgls/vol12/iss2/2

This Article is brought to you for free and open access by the Law School Journals at Digital Repository @ Maurer Law. It has been accepted for inclusion in Indiana Journal of Global Legal Studies by an authorized editor of Digital Repository @ Maurer Law. For more information, please contactrvaughan@indiana.edu.

\section{$\Psi$}

JEROME HALL LAW LIBRARY

INDIANA UNIVERSITY

Maurer School of Law
Bloomington 


\section{The Treaty Establishing a Constitution for Europe and the Democratic Legitimacy of the European Union}

\section{Elisabeth Zoller*}

On May 1, 2004, ten new Member States, most of them from Eastern and Central Europe, joined the European Union (EU). This fifth enlargement, the most important undertaken thus far in the history of the EU, closed the book on the small Europe, once centered on the western end of the continent, and paved the way to the development of a much larger Europe that already includes twenty-five Member States, but that is likely to include others-Bulgaria and Romania by 2007, then Croatia, Macedonia, and perhaps (although the topic is much debated) Turkey. Already, to accommodate these new members, EU institutions have been reformed, and the founding treaties were duly amended in the Treaty of Nice of February 28, 2001.'

As it stands today, the EU system of government functions-and could perfectly well continue functioning - based as it currently is, on treaties. The EU treatybased system, however, has been subject to mounting criticism from a democratic standpoint since 1980, with the completion of the internal market. At some point, Nice seemed likely to be the place where substantial institutional reforms would take place. This was not the case; at the end of the Nice Treaty, however, an appended declaration adopted by the heads of states and governments acknowledged:

Important reforms have been decided in Nice. . .

[The Conference] agrees that the conclusion of the Conference of Representatives of the Governments of the Member States opens the way for enlargement of the European Union....

Having opened the way to enlargement, the Conference calls for a deeper and wider debate about the future of the European Union....

\footnotetext{
* Professor of Law, Université Panthéon-Assas (Paris II); Visiting Professor of Law, Indiana University School of Law-Bloomington.

1. Treaty of Nice, entered into force Feb. 1, 2003, 2001 O.J. (C 80) 1, available at http:// europa.eu.int/comm/nice_treaty/index_en.htm (last visited Mar. 10, 2005).
} 
... [T] he Conference recognises the need to improve and to monitor the democratic legitimacy and transparency of the Union and its institutions....2

On December 15, 2001, the European Council of Laeken adopted an important declaration that stated: "The Union needs to become more democratic, more transparent and more efficient," 3 and it decided to convene a convention with a view toward drafting a "Constitution for European Citizens." " The Convention met from February 2002 to July 2003 under the leadership of the former French president, Valéry Giscard d'Estaing. It took sixteen months to prepare a draft constitution, which was presented to the European Council on July 18, 2003. ${ }^{5}$ The intergovernmental conference that took place in Brussels, from June 16 to 18,2004, resolved the last questions that the Convention had left undecided and open to discussion (in particular, the representation of states on the Commission). The draft treaty was amended slightly, and on June 18, 2004, the twenty-five heads of states and governments adopted the text of the Treaty Establishing a Constitution for Europe. ${ }^{6}$ The text was translated into the twenty official languages of the Union, and it was formally signed by the Member States in Rome (where the first Rome Treaty was signed) on October 29, 2004.

The Treaty Establishing a Constitution for Europe is a voluminous text of 341 pages and 448 articles that marks the first time Europe has had a formal constitution. As was intimated at the end of the Nice conference and plainly stated in the Laeken Declaration, the major, if not only, reason to switch from a treatybased to a constitution-based system was the necessity for the Union "to become more democratic." Why? Because since its inception, but even more visibly to-

2. Declaration of Nice, 2001 O.J. (C 80) 85, art. 23, paras. 1-3, 6.

3. Council of the European Union, Presidency Conclusions: European Council Meeting in Laeken 14 and 15 December 2001, Annex I, Laeken Declaration on the Future of the European Union 21, SN 300/1/01 REV 1, available at http://ue.eu.int/ueDocs/cms_Data/docs/pressdata/en/ ec/68827.pdf (last visited Mar. 10, 2005) [hereinafter Laeken Declaration].

4. Id. at 23 .

5. See European Convention, Secretariat, Draft Treaty Establishing a Constitution for Europe, CONV 850/03, available at http://european-convention.eu.int/docs/Treaty/cv00850.en03.pdf (last visited Mar. 10, 2005) [hereinafter Draft Treaty].

6. See Conference of the Representatives of the Governments of the Member States, Provisional Consolidated Version of the Draft Treaty Establishing a Constitution for Europe, 2004 O.J. (C 310) 1, available at http://europa.eu.int/eur-lex/lex/JOHtml.do? uri=OJ:C:2004:310:SOM:EN:HTML (last visited Mar. 10,2005) [hereinafter Provisional Consolidated Version of the Draft Treaty]. 
day, EU institutions exercise legislative powers over European citizens; these institutions are empowered to take "action that [has] the purpose and effect of altering the legal rights, duties, and relations of persons,"7 without these persons having the conviction that these powers are legitimate, as are powers exercised by duly elected and mandated national bodies. This system of government is seriously undermined by the perception that its decisions come from a smug, sometimes arrogant bureaucracy that is accountable to no one. The Laeken Declaration, which launched the project of a constitution for European citizens, was extremely lucid, if somewhat understated, on that issue when it acknowledged:

Within the Union, the European institutions must be brought closer to its citizens. Citizens undoubtedly support the Union's broad aims, but they do not always see a connection between those goals and the Union's everyday action. They want the European institutions to be less unwieldy and rigid.... More importantly, however, they feel that deals are all too often cut out of their sight and they want better democratic scrutiny. ${ }^{8}$

So much energy was mobilized to draft a constitution for Europe because a constitution was supposed to cure the Union of the deadly malady that is sapping it, the so-called "democratic deficit." Ameliorating that deficit was the priority of the Constitutional Convention, as indicated by the mission assigned to it by the European Council of Laeken: "More democracy, transparency and efficiency in the European Union." ${ }^{10}$ Evidence that "more democracy" was the top priority of the Convention could be found in the citation to Thucydides that originally opened the Draft Treaty prepared by the Convention presided over by Valéry Giscard d'Estaing: "Our Constitution ... is called a democracy because power is in the hands not of a minority but of the greatest number." $T$ The inter-

7. This definition of legislative power can be found in Immigration and Naturalization Service $v$. Chadha, 462 U.S. 919, 952 (1982).

8. Laeken Declaration, supra note 3, at 20.

9. See Bill Newton Dunn, Why the Public Should Be Worried by the EEC's Democratic Deficit (1988) (Bill Newton Dunn has been a member of the European Parliament since 1979. In this pamphlet, he coined the phrase "democratic deficit.").

10. Laeken Declaration, supra note 3, at 22.

11. Draft Treaty, supra note 5, at 3 (quoting Thucydides, History of the Peloponnesian War bk. II, para. 37 (Rex Warner trans., 1954)). 
governmental conference decided to delete that citation on the grounds that it was incompatible with the principle of equality of states. Although that deletion may not, in itself, say much about the real democratic content of the project, its symbolic significance is telling.

Contrary to the expectations raised in 2000 by the speeches of the German Minister for Foreign Affairs, Joska Fisher, ${ }^{12}$ and the French President, Jacques Chirac, ${ }^{13}$ in which both leaders called for a European constitution that would create a democratic European Union, the Draft Treaty Establishing a Constitution for Europe, adopted in Brussels in June 2004, has not established a real democracy. Power is still not with the people, but with the states. The democratic legitimacy of the European Union is still not grounded on a solid foundation, and the democratic deficit remains high. Real power remains with the bureaucracy-the Commission-not with the people. Part I of this paper explores why this remains the case, despite a few cosmetic improvements to the democratic content of the project. Parts II and III explore how the project was unable to go beyond the entrenched governmental power of the European bureaucracy, and eventually reinforced it, making democracy an almost insuperable task.

\section{The Hollow European Democracy}

The form of democratic government that emerged from the revolutions of the late eighteenth century both in the United States and in France is representative democracy; some also call it elective democracy, in which the people govern themselves through elected representatives. It is based on popular sovereignty, which means "government of the people, by the people, and for the people." ${ }^{14}$ Concretely, these ideals are implemented through the lawmaking and law enforcement functions and, particularly, through the organization of the legislative and executive powers. First, regarding the making of the law, citizens

12. Joska Fisher, From Confederacy to Federation-Thoughts on the Finality of European Integration, Speech at Humboldt University in Berlin, Germany (May 12, 2000), available at http:// www.auswaertiges-amt.de/www/en/ausgabe_archiv?archiv_id=1027 (last visited Mar. 3, 2005).

13. Jacques Chirac, Our Europe, Speech at the Bundestag (June 27, 2000), available at http:// www.fedtrust.co.uk/default.asp? pageid $=2158$ mpageid $=215 \&$ groupid $=8$ (last visited Mar. 25 , 2005) (English).

14. Abraham Lincoln's celebrated definition of the Republic in the Gettysburg Address has been adopted by France. See Fr. Const. art. 2 ("gouvernement du peuple, par le peuple et pour le peuple"). 
can be subject only to laws to which they have consented by electing those who make them. Second, regarding enforcement of the laws, the enforcers of the law must be accountable to the people, either directly by the ballot and the sanction of nonreelection, or indirectly by ministerial responsibility before Parliament, which is itself accountable to the people.

Legislative power, as it is currently organized in the EU treaty-based system of government and duplicated in the constitution-based system of the Draft Treaty Establishing a Constitution for Europe, does not conform to the two previously mentioned requirements. It is exercised within an "institutional triangle" made up of three components: the Parliament, the Council of Ministers, and the Commission. The European Council must be set aside in this context as it does not participate in the legislative function. This point has been expressly codified in the Constitution. ${ }^{15}$ Therefore, taking into consideration the three abovementioned organs only, the questions that must be raised to evaluate the democratic content of the lawmaking function in the EU are these: Are these bodies elected by the people? Do they govern in the name of a mandate given to them by the people? Whom do they represent?

The Parliament is composed of deputies who represent the people of the $\mathrm{EU}$; the Council is composed of ministers who represent the governments of the states; and the Commission is composed of persons who represent nobody but themselves, as they are "members... chosen on the ground of their general competence and European commitment from persons whose independence is beyond doubt." ${ }^{16}$ The functions of the three organs are discrete. Neither the Parliament nor the Council has the power to initiate laws; their power is limited to taking a position on texts conceived by others. In accordance with the so-called "co-decision procedure," the Parliament and the Council adopt or reject the bills presented to them by the Commission. ${ }^{17}$ The Council and the Parliament may prevent the bills of the Commission from becoming laws and they may also amend, revise, and modify them, but they may not get their own bills through.

15. See Provisional Consolidated Version of the Draft Treaty, supra note 6, art. I-21, para. 1 ("[The European Council] shall not exercise legislative functions.").

16. Id. art. I-26, para. 4.

17. Under the Draft Constitution, the Parliament is practically always on an equal footing with the Council of Ministers in the exercise of its veto power over the Commission's drafts. In other words, unlike the previous situation where the Parliament's veto power was not always required, under the Draft Constitution, the Parliament is now on par and fully associated with the Council when it comes to rejecting a proposal of the Commission. 
The Commission possesses an absolute monopoly on legislative initiative. No law may come into force and, therefore, no policy may be carried out, without the Commission's prior acquiescence.

There is little doubt that the Commission is the most powerful organ of the Union, insofar as nothing can be carried out without this organ's initiating it in one way or another. With legislative initiative that it alone can exercise, the Commission holds the key to all other powers, the initial power without which all other powers would lie dormant. Because of this monopoly on the right of legislative initiative, the Commission has the power to shape the destiny of the Union. It is at the center of power because it is endowed with the ultimate and the most important of all powers, the so-called "governmental power." $18 \mathrm{Mem}$ ber States are well aware of the power of the Commission, as they showed by their fierce resistance to the first draft of the EU Constitution, which, in order to keep a small-staffed commission with no more than fifteen members, provided for fake commissioners without a right to vote. The governmental power of the Commission-its ability to steer the EU toward those destinations that it sees as most fit for the welfare of the Union-is the basis of the so-called "community method of government," a basic tenet of the EU institutional structure. ${ }^{19}$

The community method of government originated in the first community, namely, the European Coal and Steel Community (ECSC) involving France, Germany, Italy, and the three countries of the Benelux (Belgium, the Netherlands, and Luxemburg). The ECSC was created by the Treaty of Paris in 1950, but its full development dates from the Rome Treaty of 1957, which created the Common Market. The Schuman Declaration of 1950 had proposed "to put the entire coal and steel production under a High Authority ... made of indepen-

18. The notion of governmental power originates in the works of Saint Thomas Aquinas. See generally Saint Thomas Aquinas, On the Governance of Rulers (De Regimine Principum) (Gerald B. Philan trans., 1938) (The "angelic doctor" explains that men living together must be diligently ruled by somebody, i.e., led toward the due end to which their whole life and all their actions are ordered.). More recently, the keenest analyst of governmental power was Michel Foucault. See Michel Foucault, La gourvernementalité, Dits et écrits, ToME III (1976-1979) 635-57 (1994) (for an English translation by Pasquale Pasquino, see Michel Foucault, Governmentality, in The Foucault Effect, Studies in Governmentality 87-104 (Graham Burchell et al. eds., 1991)).

19. See generally Youri Devuyst, The Community-Method after Amsterdam, 37 J. Common MARKet Stud. 109 (1999) (providing a historical analysis); Youri Devuyst, The European Union's Constitutional Order? Between Community Method and Ad Hoc Compromise, 18 Berkeley J. INT'L L. 1 (2000). 
dent personalities designated on a parity basis by national governments." ${ }^{20}$ In 1957, when the drafters of the European Economic Community Treaty created the Commission, they were inspired by this concept of the High Authority. They decided to give the Commission the same status as the High Authority although its functions were quite different. The major difference was legislative power, which the High Authority did not have under the 1950 Treaty because all the rules to be applied to the coal and steel market were contained in the Treaty. The High Authority was an adjudicatory body; it was in charge of applying the rules of the Treaty to individual situations in the same manner that, say, a federal agency would apply rules to private parties. Because of the respect it had gained over the few years of its existence, the High Authority soon became a model for the drafters of the Rome Treaty; they gave the Commission, which would parallel the High Authority in the Common Market, the same status of independence. However, they considerably increased its power by giving it a large rulemaking authority in addition to its traditional adjudicatory function. The end result of this institutional structure is that the EU is governed by an independent agency - independent from the Member States, from the governments, and from the people. EU policies are designed not by elected representatives, as democracy demands, but by the Commission, a body that, according to article 26(7) of the EU Draft Constitution, "shall be completely independent [and whose] members shall neither seek nor take instructions from any government or other institution, body, office or entity." The EU is governed by independent experts, not by elected representatives.

The community method of government, which relies on an independent college of men and women for deciding the fate of millions of people, is not a democratic method of government, and nobody pretends it is. ${ }^{21}$ The measure of true democracy is the dependence of the rulers on the governed; it takes concrete form

20. C.A. Colliard \& A. Manin, Droit international et histoire diplomatique, Tome II: L'Europe, Montchrestien 306, 308 (1970) (author's translation). The Schuman Declaration is also available at http://www.diplomatie.gouv.fr/archives/dossiers/schuman/pages/33la.html (last visited Mar. $10,2005)$.

21. See, e.g., Lee A. Casey \& David B. Rivkin Jr., Europe in the Balance, PoL'y Rev., available at http://www.policyreview.org/jun01/casey.html; Paul Craig, The Community Political Order, IND. J. Global Legal Stud., Winter 2003, at 79 (2003); Renaud Dehousse, La participation des citoyens européens, in Constitution Européenne, democratie et droits de L'homme 197, 199-201 (Gerard Cohen-Jonathan \& Jacqueline Dutheil de la Rochère eds., 2003); Michael Newman, Democracy, Sovereignty and the European Union 173-200 (1996). 
with the ballot box and the right to elect and remove from office those who govern. To be fair, the founding fathers of the European Economic Council (EEC) had no choice at the beginning of 1950 but to set democratic methods of government aside. They chose the system they did because democracy was virtually impossible at that time in Europe. Before putting into place a democratic Europe, Europe as a polity had to be created. According to Paul Reuter, independence for the High Authority was a last-resort solution that was conceived to "solve the problem of how to create a Europe without Europeans." 22 Indeed, there was at the beginning no government, no parliament, no institution capable of conveying the aspirations of the European people. It was thought at that time that an independent body with a highly respected moral authority could act as wise men, calming passions and showing the fair way to interpret the rules of the Treaty. However, there was no legislative power in the ECSC, and the main function of the High Authority was to apply Treaty rules to individuals and corporations. ${ }^{23}$ As an adjudicatory body, the High Authority had to be independent by reason of the rule of law and in order to apply the rules of the Treaty equally to all. At that time, the rationale for an independent High Authority was very similar to that advanced in the United States to justify the independence of certain regulatory agencies.

In 1957, the newly created Commission of the Common Market was also invested with adjudicatory functions, particularly in the field of competition policy, but in addition to these, it was granted legislative powers. In contrast to the High Authority, which had executive functions only, the EEC Commission was given a decisive role in the legislative process. The drafters of the Rome Treaty decided that the Council of Ministers, to which large lawmaking authority was to be granted under the EEC Treaty, could adopt laws ("rules" or "directives" in EEC parlance) only after they were formally proposed by the Commission. The Commission was given exclusive power to draft EEC laws and, furthermore, if the Council wanted to depart from the Commission's proposal, it could do so only by a unanimous vote. This elaborate mechanism, very "original" to say the least ${ }^{24}$ gave the Commission a monopoly in initiating EEC laws. In giving that power to the Commission, the drafters of the Rome Treaty gave to the Commission the most important of all state powers, namely, the governmental power.

22. Paul Reuter, La Communauté européenne du charbon et de l'acier 51-52 (1953).

23. Id. at 49.

24. Paul Reuter charitably characterized the system as "original." See Paul Reuter, OrganisaTIONS EUROPÉENNES 226 (1965). 


\section{The Entrenched Governmental Power of the European Bureaucracy}

Because of a rich and tormented constitutional history that encompassed all political regimes, from the most democratic to the most authoritarian, French jurists know that the governmental power was created by Napoleon Bonaparte in the so-called "Constitution du 22 Frimaire, an VIII" (adopted on December 13, 1799). The genius of that constitutional document was that it gave a monopoly on legislative initiative to the executive branch (article 25: "New laws shall be promulgated only when the project for them shall have been proposed by the Government, communicated to the Tribunate, and decreed by the CorpsLégislatif"). ${ }^{25}$ This novelty revolutionized constitutional theory in two ways. First, it reinvented the notion of executive power by elevating it above its traditional, subordinate role of enforcing the law, to which it had been confined since 1789 , and putting it in a higher position than legislative power itself, the sovereign power at that time. Second, it forced constitutional scholars to completely rethink the theory of separation of powers, because while it sets up a political system that on its face seemed to be an application of that theory (concretely, it established two legislative chambers-the "Tribunate" or lower chamber and the Corps-Législatif or upper chamber-and an executive organ led by three consuls), in reality, it completely denatured the theory, insofar as power was no longer a check on power and the legislature became the servant of the executive. In order to assist the executive in drafting laws, an advisory body-the Conseil $d^{\prime} E$ tat (Council of State) - was established on an equal footing for the purpose of "drawing up projects of law and regulations of public administration" (article 52 of the Constitution, Year VIII). ${ }^{26}$

The ingenious mechanism of the Constitution of Year VIII survived Napoleon and had a long posterity among all French regimes with a strong executive. In the nineteenth century, it was to be found in both the Restoration ${ }^{27}$ and the Second Empire, ${ }^{28}$ in which only the executive had the power to initiate legislation. As for the twentieth century, it may be noted that the current French Con-

25. Frank Malloy Anderson, The Constitutions and Other Selected Documents Illustrative of the History of France 1789-1901, at 274 (1904).

26. Id. at 277 .

27. Id. at 460 (Constitutional Charter of June 4,1814 , art. 16).

28. Id. at 545 (Constitution of January 14, 1852, art. 8). 
stitution of October 4, 1958, without formally embodying the same mechanism, is structured in such a way as to lead to a very similar result. The government shares the right to initiate legislation with deputies and senators, but it has priority in setting the agenda of Parliament, ${ }^{29}$ which means that proposals drafted by the Executive (and always vetted by the Conseil d'Etat before going to Parliament) may always be debated and voted upon before the bills of the Members of Parliament (MPs), should the government so choose.

French liberal Benjamin Constant was quite right when he ironically noticed that the executive branch's monopoly on drafting legislation ought to be regarded as a masterpiece. ${ }^{30}$ To be sure, it is a great one, because its end result is to deprive representatives of the people of the right to initiate legislation without having to formally put it in writing. The mechanism is admirable insofar as it crowns democracy and, at the same time, ousts it. Seemingly, democracy is alive and well. The representatives of the people are assembled; they deliberate, discuss, criticize, amend (subject to executive approval), and vote upon the texts presented to them. In truth, the reality of power completely escapes them. They do not govern; they are governed.

One does not need a law degree to understand the parallels between the current EU system of government and the consular system of government set up by Bonaparte. Both systems are based on the very same principle. One organ onlythe Conseild'Etat under the Consular regime, the Commission in the EU government-is in charge of drafting legislation. The Commission has even succeeded in becoming more powerful than the Conseil d'Etat for, whereas the Conseil d'Etat was under the command of the three consuls, the Commission is under the command of no one. The Commission, composed of eminent members known for their European commitment, is "independent"; because of its independence, it is entrusted with the responsibility to "promote the general interest of the Union and take appropriate initiarives to that end." 31 The representatives of the people are only called on to approve or disapprove its initiatives.

That said, the real difficulty is perhaps not where it seems to be. From a democratic standpoint, the most objectionable feature of this system of govern-

29. Fr, Const, art. 48.

30. Benjamin Constant, Annexes aux principes de politique, in Benjamin Constant \& Marcel Gauchet, Ecrits politiques 538 (1997).

31. Treaty Establishing a Constitution for Europe, signed Oct. 29, 2004, art. I-26(I), 2004 O.J. (C 310). 
ment is less the exclusive right of the Commission to initiate legislation than is its total independence. For, in a parliamentary regime, the cabinet possesses the same monopolistic power, certainly not de jure (since MPs may always initiate bills), but de facto, because the prime minister is himself a MP and is virtually the originator of most bills discussed by Parliament as the head of the government and the leader of the majority. It is worth noting here that it is precisely because of their de facto monopoly in initiating bills that parliamentary governments are regarded as "efficient" and can carry out their intensive legislative programs. What is really objectionable in the EU system of government is that the Commission enjoys that de facto monopoly while also being independent.

The independence of the Commission is regarded as the Holy Writ of the community method of government. Originally, it was justified by the legal nature of the functions entrusted to the High Authority of the ECSC, which was, as noted, very much like an administrative agency vested with adjudicatory powers. Mutatis mutandis, one could have applied to the High Authority exactly what Justice Sutherland said of the Federal Trade Commission in Humphrey's Executor v. United States: That it

is to be nonpartisan; and it must, from the very nature of its duties, act with entire impartiality. It is charged with the enforcement of no policy except the policy of the [Treaty]. Its duties are neither political nor executive, but predominantly quasi-judicial and quasi-legislative. ... [I]ts members are called upon to exercise the trained judgment of a body of experts "appointed by law and informed by experience." 32

In 1957, when the drafters of the EEC Treaty modeled what would become the Commission on the High Authority, they did not see fit to temper the principle of independence, although, as applied within the EEC treaty system, it necessarily led to granting true legislative powers to an independent bureaucracy that is accountable to no one. At that time, nobody objected to the independence of the Commission because independence was regarded as a guarantee of impartiality. This fatal mistake is even today taken as the most important principle of the EU system of governance.

32. Humphrey’s Executor v. United States, 295 U.S. 602, 624 (1935) (substituting "The High Authority" for "commission" and "Treaty" for "the law") (citation omitted). 
Independence and impartiality are not, of course, two sides of the same coin. U.S. legal scholars have learned the distinction over more than two centuries of constitutional case law. If the nine justices of the U.S. Supreme Court are always independent because they do not depend on anyone and no one can do anything against them, they are seldom impartial insofar as (save for these rare cases which they decide unanimously) they always take sides, as may be observed by anyone reading their diverse and thus partial opinions in most cases. ${ }^{33}$ Conventional wisdom in the EU system of government, however, holds that impartiality is the other side of independence. It is believed that, because of its independence, the Commission is the designated protector of small states or, in the same vein, the vigilant enforcer of treaties. Such reasoning overestimates the status of the Commission. Small states are protected less by the independence of the Commission than by treaty rule, according to which, when the Council wants to depart from a Commission's legislative proposal, it may do so only unanimously. In the same manner, treaties are vigilantly enforced not because the Commission is independent, but because the treaty contains a rule that gives it the power to lodge complaints with the Court whenever the treaty is breached by Member States. It is more accurate to say that these two functions are better exercised if the Commission is independent, not that these functions are exercised because the Commission is independent.

The independence of the Commission is certainly not, in and of itself, a bad thing. It must be kept as a prerequisite for any adjudicatory function the Commission is entrusted with. Whenever the Commission acts as an administrative agency, that is, whenever it applies general rules to individual situations, it must be independent because it is applying laws and laws must always be equally applied. This is the common foundation of the British "rule of law," the German Rechtsstaat, or the French Etat de droit. But, when it is a matter of making the law, not applying it, the independence of the Commission contributes to the belief, now entrenched, that to be good, a government must be independent. On the contrary, whenever governments are independent from the governed, democracy no longer exists. The reign of democracy is certainly not the reign of those, in Tocqueville's words, "who present themselves as strong champions of the

33. Unanimous decisions are an oddity in Supreme Court case law. Such is, however, the case with the landmark decision in Brown v. Board of Education, 347 U.S. 483 (1954), which appears to be the least disputed case among all those decided by the Court. See the illuminating demonstration by Jean-Marie Denquin, Justice constitutionnelle et justice politique, in LA NOTION DE JUSTICE CONSTITUTIONNELLE (forthcoming 2005). 
majority... who know what is best for the people... without consulting [them]." ${ }^{34}$

Democracy is not the reign of the experts, or the wise men, it is "the reign of the politician." ${ }^{35}$ This is so because, in a democracy, popular suffrage is the source of power or, in other words, "the law is the expression of the general will," not the will of a few, no matter how wise or learned they may be. These ideas, which were at the core of the republican tradition as it came into being in the United States and in France at the end of the eighteenth century, are on the wane, if not already dead. Under the term gouvernance, which does not exist in the language of traditional French political theory and which does not signify anything very precise, except insofar as it is distinct from gouvernement, which is subject to the corrupting influence of politics, the belief has grown that a good government must be independent. In France, the high civil service is the most ardent champion of this idea, particularly in the field of regulation. Government by independent experts is at odds with democratic principles; it is, nevertheless, the basic foundation of the EU system of government.

\section{Nurturing European Bureaucracy}

Despite its undemocratic character, the monopoly of the Commission in drafting EU laws is the most cherished and best protected principle of the EU system of government. All efforts undertaken thus far by the EU Parliament to break that monopoly and to be given the right to initiate bills in the manner of national parliaments have failed. Curiously enough, the European Parliament eventually joined the Council of Ministers in its opposition to breaking the Commission's monopoly. How can we explain the very strange fact that these institutions, all of them composed of men and women deeply attached to democratic values, are satisfied with rules that undermine the values that they claim to support? What is the reason for this contradiction?

The explanation is quite simple. The Commission's monopoly on initiating European legislation effectively allows those who govern, whether they are elected by the people (EU Parliament) or designated by democratically elected governments (Council of Ministers), to evade their responsibilities. It keeps

34. Alexis de Tocqueville, Democracy in America 456 (Arthur Goldhammer trans., 2004).

35. Joseph Schumpeter, Capitalism, Socialism and Democracy 284-302 (3d ed. 1950). 
them from doing what democracy compels them to do-to make choices, to make decisions on the behalf of their constituents-in short, to govern. It enables them to pass on to a college of experts, which is, practically speaking, accountable to no one, responsibility for making choices that will affect the lives of millions of people.

It is true that the Draft Treaty to Establish a Constitution for Europe makes a few improvements that tend toward a more democratic system. First, it rules out this system of government by experts in the field of common foreign and security policy, which is the least that could be done given the impact of that policy on people's lives. ${ }^{36}$ With regard to EU internal policies, the monopoly of the Commission on initiating legislation remains intact, and government by experts is still the rule. At most, the Draft Constitution makes a few small improvements in the direction of both representative and participatory democracy. Regarding representative democracy, the Draft Constitution provides that the European Council shall propose to the European Parliament a candidate for President of the Commission, "[r]aking into account the elections to the European Parliament," and that the candidate "shall be elected by the European Parliament by a majority of its members." 37 The Draft Constitution gives the law force by providing that "[t]he Commission, as a body, shall be responsible to the European Parliament." 38 However, as demonstrated further down, that embryo of "responsible government" may well turn out to be wishful thinking so long as the basic principle in the status of the Commission, its independence, remains intact. Regarding participatory democracy, which supplements representative democracy - without, however, replacing it-the Draft Constitution provides that one million citizens may "take the initiative" in the Union's legislative process. However, one million citizens are powerless before some twenty EU experts, as this right is limited to taking the "initiative of inviting the Commission ... to submit [a] proposal." ${ }^{39}$ Essentially, EU citizens are in no better position than were deputies and peers under the Restoration of Louis XVIII, the French constitutional monarchy of the early nineteenth century, who were allowed "to beg the King to initiate legislation."

36. Treaty Establishing a Constitution for Europe, supra note 31, arts. I-26(2), III-295, 296(1).

37. Provisional Consolidated Version of the Draft Treaty, supra note 6, art. I-27, para. 1.

38. Id. art. I-26, para. 8.

39. Id. art. I-47, para. 4. 
The drafters of the EU Constitution go even further in their contempt for the people by making the Commission more independent than it used to be. Since the beginning of the Common Market, independence from political interference was guaranteed only to the members of the Commission taken individually, just as judicial independence is guaranteed to judges as persons: "The members of the Commission shall ... be completely independent in the performance of their duties.... Each Member State undertakes to respect this principle and not to seek to influence the Members of the Commission in the performance of their tasks." ${ }^{40}$ Under the Draft Constitution, independence is still guaranteed to members of the Commission taken individually (with the abovementioned exception for the ministry in charge of common and foreign security policy). But in addition, complete independence is guaranteed also to the Commission as a body: "In carrying out its responsibilities, the Commission shall be completely independent."

The result of this broad, extended independence may well make the Commission's political responsibility to Parliament the most elusive accountability to grasp. For there is a total contradiction between granting complete independence to the Commission and holding it accountable to the Parliament. If the Commission is really politically responsible to Parliament, and if, accordingly, Parliament may vote on a censure motion on it, this means that Parliament may hold the Commission accountable for political mistakes or failures. In practice, if Parliament may really do so, it means concretely that it may criticize the Commission for not carrying out the policies that Parliament-as a politically elected body-considers the most appropriate for the Union, in the same manner that parliaments may criticize the cabinet in any parliamentary regime. However, if the European Parliament could impose that kind of political check on the Commission, the Commission would be politically accountable to the Parliament; that is, it would no longer be independent. The only way this contradiction can be resolved is to interpret any alleged fault that might trigger a censure motion as a legal fault, that is, a fault against the law, not against a policy. A legal fault, as opposed to a political one, would be, for example, "treason, bribery or other high crimes or misdemeanors"; in other words, a legal fault is the kind of misconduct that in seventeenth century England-or in the United States today-

40. Treaty Establishing the European Community, 2002 O.J. (C 325) 120, available at http:// europa.cu.int/eur-lex/lex/en/treaties/dat/12002E/htm/12002E.html (last visited Mar. 10, 2005).

41. Id. art. I-26, para. 7. 
would be used to justify an impeachment procedure. That kind of misconduct is precisely the type of fault that forced the Commission directed by Jacques Santer to collectively resign in 1999 for corruption and bribery. This means that the alleged improvements in the political accountability of the Commission are illusory and cannot bring about the expected changes without a complete change in the Commission's status. For the Commission to be politically accountable to Parliament, it must be dependent on the elected representatives. The Draft Constitution is at odds with that prerequisite.

If the EU Constitution is adopted, the laws of the Union as well as the policies it carries out will be decided, as before, in secrecy, ${ }^{42}$ by an unelected college of experts who are independent, sole judges of what the general interest of the Union requires, and who are, for all practical purposes, accountable to no one. The Draft Constitution puts the Commission's monopoly on initiating EU legislation behind a legal fortress for years to come. Not only does it confirm the past in providing that "Union legislative acts may be adopted only on the basis of a Commission proposal, ${ }^{\prime 43}$ it also strengthens the key position of this body by providing that "the Commission shall promote the general interest of the Union" ${ }^{\prime 4}$ with the implication that only the Commission can do so. The Commission's monopoly on the initiative of EU laws remains an insuperable obstacle that limits the horizon of enlightened European democracy.

As long as the Commission maintains the exclusive right of initiating EU legislation, European citizens will pay no attention to the European Parliament. For democracy to materialize and for the people to govern, candidates on the ballot must go to the voters with a program for the years to come. Today, and tomorrow, should the Draft Constitution be adopted, this prerequisite is simply out of reach. The belief that the democratic deficit may be overcome by increasing the powers of democratically elected national parliaments in the EU decisionmaking process, in particular by giving them an advisory function in EU legislative process, is counterproductive; it entrusts these national representatives with a mandate to do what they have no power to accomplish. Moreover, such a belief is politically dangerous because, at the end of the day, voters will

42. Interestingly enough, transparency of the proceedings of the Union institutions applies to the Parliament as well as the Council of Ministers, not to the Commission. European Convention, Secretariat, Text of Part I and Part II of the Constitution, CONV 797/1/03, available at http:// european-convention.eu.int/docs/Treaty/cv00797-re01.en03.pdf (last visited Mar. 10, 2005).

43. Id. art. I-26, para. 2.

44. Id. art. I-26, para. 1 . 
realize that while their national representatives can certainly help them at the national level, they are powerless at the European level. The pretense that the democratic deficit is reduced by reinforcing the role of national parliaments misleads the citizenry both on the meaning of the dual citizenship (community and national) that they were endowed with more than ten years ago, and on the need to distinguish between the two so that they are better kept under the control of national political parties.

Only in the EU Parliament can European citizens be fully represented. Only in the EU Parliament can EU citizenship be meaningful. As the sole directly elected body in the EU institutional arrangement, the EU Parliament is the only place where European public opinion can influence the destiny of the Union. The EU Parliament is emphatically the place for the European general will to make itself known. So long as the EU Parliament is deprived of the right to initiate legislation, that general will is certain to remain silent, and European laws will be the exclusive province of leaders and elites, as Jacques Chirac said in a much celebrated speech before the Bundestag on June 27, 2000. ${ }^{45}$ The EU system of government, as conceived by the Draft Constitution, is simply this: an independent regulatory agency that alone determines the general interest of the Union. The treaty-based EU government is not democratic today, nor will it be democratic tomorrow, should it come to be based on this constitution.

\section{Conclusion}

Where does that lead us? Simply to this: a constitution is not necessary to create a democracy. The United Kingdom, New Zealand, and Israel are cases in point, for even without formal constitutions, these countries are true democracies. They have constitutions in the substantive, though not in the formal, sense. Their constitutions are to be understood under the classical definition given by Bolingbroke in 1733: "By Constitution we mean, whenever we speak with propriety and exactness, that assemblage of laws, institutions and customs, derived from certain [fixed] principles of reason ... that compose the general system, according to which the community [has] agreed to be governed." ${ }^{46}$

45. Chirac, supra note 13.

46. Letter $X$, in Henry St. John Bolingbroke, A Dissertation Upon Parties; in Several Letters to Caleb D'Anvers, Esq.; Dedicated to the Right Honourable Sir Robert Walpole (3d ed. 1735). 
Under that definition, the EU already possesses a constitution, in the same sense that the United Kingdom, New Zealand, and Israel do. It has a government composed of several organs (a Parliament, a Commission, a European Council, a Council of Ministers, and a Court) and it has laws and customs that bind European institutions and the governments of Member States, not as a matter of rhetoric, but as a matter of law, as these laws are enforced by a court. So why does it need to adopt a formal constitution? Because "constitution" is a magical word. A constitution is an act adopted by the people. The Member States are well aware of the democratic import of the word constitution. Most of them have chosen a procedure with ratification by referendum for adopting the Treaty Establishing the Constitution on the implicit, unavowed, but very true ground that states cannot make a constitution; only the people can adopt a constitution. The Treaty Establishing a Constitution for Europe will give a democratic basis to the EU system of government, but it will be only that-a basis, not democracy itself.

This sad result is all the more regrettable because it was not inevitable. The European Convention might have drafted a very different constitution had it not forgotten that it was to create, first of all, a democracy. The heads of states and government leaders had already paved the way in the Laeken Declaration, when they invited the Convention to put forward a draft constitution that would make the Union "more democratic, more transparent, and more efficient." These carefully chosen adjectives clearly called for a parliamentary regime: democratic, because it is made of ministers elected by the people; transparent, because it governs in accordance with an agenda publicly discussed in open debate; and efficient, because it carries out its public policies with the support of a parliamentary majority. Although it is unlikely that the next EU government will be truly democratic, perhaps the subsequent government will be. At any rate, nothing in the Draft Treaty Establishing a Constitution prevents such an evolution. 